\title{
Ursodeoxicholic Acid in the Treatment of Intrahepatic Cholestasis of Pregnancy
}

\author{
MADALINA OTILIA TIMIRCAN ${ }^{1}$, LAVINIA MARIA HOGEA ${ }^{2 *}$, ANDREEA CIRLOGEA ${ }^{1 *}$, IOANA COJ OCARU ${ }^{1}$, IRINA ZORZOANA ${ }^{1}$, \\ LAURA ALEXANDRA NUSSBAUM², ROXANA FOLESCU³ , BOGDAN GHEORGHE HOGEA ${ }^{4}$, MIHAELA SIMU², \\ ALINA MIHAELA PASCU ${ }^{5}$, MIHAELA BOANCA**, EVELINA GOMOI ${ }^{1}$ \\ ${ }^{1}$ Municipal Emergency Clinical Hospital, Obstetrics and Gynecology, 16 December 1989 Sq., 300173, Timisoara, Romania \\ ${ }^{2}$ Victor Babes University of Medicine and Pharmacy, Department of Neurosciences, 2 Eftimie Murgu Sq., 300041, Timisoara, \\ Romania \\ ${ }^{3}$ Victor Babes University of Medicine and Pharmacy, Department of Anatomy and Embryology, 2 Eftimie Murgu Sq., 300041, \\ Timisoara, Romania \\ ${ }^{4}$ Victor Babes University of Medicine and Pharmacy, Department of Orthopedics, Urology and Medical Imaging, 2 Eftimie Murgu \\ Sq., 300041, Timisoara, Romania \\ ${ }^{5}$ Transilvania University of Brasov, Faculty of Medicine, 29 Eroilor Blvd, 500036 Brasov, Romania \\ ${ }^{6}$ Grigore T. Popa University of Medicine and Pharmacy, Faculty of Medicine, 16 Universitatii Str., 700115, Iasi, Romania
}

Intrahepatic choleastasis of pregnancy (ICP) also called obstetric cholestasis (OC) is a liver condition of pregnancy characterized by pruris, elevation in circulating bile acide and liver derangement, associated with adverse fetal outcomes such as preterm labor and stillbirth. The frontline treatment for ICP is Ursodeoxicholic acid (UDCA). This medication has been shown to be superior to all othermedications in the treatment of ICP, and has been proved safe for both mother and baby.

Keywords: intrahepatic cholestasis, ursodeoxicholic acid, pregnancy, pruritus

Ursodeoxicholic acid (UDCA) is the most commonly recomended drug in pregnancy pruritus caused by cholestasis. The chemical formula of UDCA is $\mathrm{C}_{24} \mathrm{H}_{40} \mathrm{O}_{4}$ (fig 1.). It's molar mass is $392.56 \mathrm{~g} / \mathrm{mol}$.

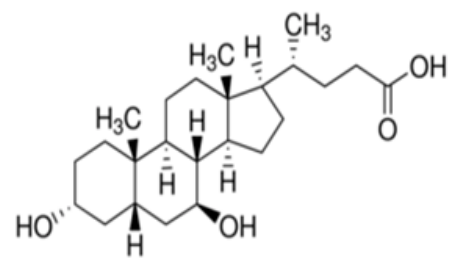

Fig. 1. Chemical formula of Ursodeoxicholic acid (UDCA)

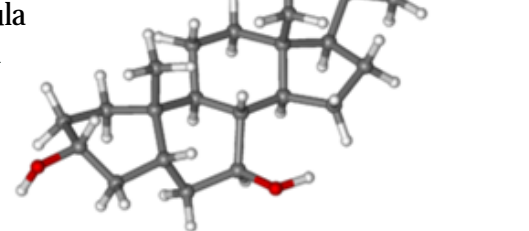

Obstetric cholestasis (OC), also called intrahepatic choleastasis of pregnancy (ICP) is a pruritic condition of pregnancy, characterized by elevated serum bile acide, and other signs of liver disfunction and is diagnosed after exclusion of other cause of cholestasis [1-5].

The incidence of ICP is dependend on geographic location andethnicity: in China has been estimated at 1.2\%.

Pregnancy increases the sensitivity of the bile ducts to estrogen, and cholestasis often develops during the second and third trimesters of pregnancy. It is the second most common cause of jaundice during pregnancy, with a variable incidence, between $0.1-15.6 \%$. The incidence is higher in South American and Scandinavian countries $(9.2 \%$ $-15.6 \%$, respectiely, $1.5 \%)$ than in Europe $(0.1 \%-0.2 \%)$.

The etiology is multifactorial, considered as an interaction of genetic, endocrine and environmental factors.
The frontline treatment for ICP is UDCA in doses of 600$2000 \mathrm{mg}$ per day [6-10]. UDCA was shown to be the most efficient therapeutic agent with proven safety and efficacy. There are many other ways that this medication may help the baby, including preventing premature aging of the placenta, reducing risk of meconium staining, protecting the baby's heart against changes induced by bile acids, restoring the placenta's ability to transport bile acids away from the baby, and protecting cells from damage due to bile acids. UDCA treatment attenuated pruritus, while serum bilirubin and alanin aminotransferase (ALT) decreased [11-13].

For some women, dexamethasone or other steroids may help reduce itching. However, it has been shown that UDCA is generally more effective. Steroids are also ineffective in reducing total bile acids. Additionally, repeated use of steroids during pregnancy may create problems with birth weight and brain development of the baby [14-17].

\section{Experimental part}

Study Population and Methods

This retrospective study was performed in the department of Obstetrics and Gynecology - Clinical Emergency Municipal Hospital Timisoara, Romania, between 2016-2018.

The diagnosis of ICP was considered in case of maternal itching during pregnancy with other causes of cholestasis excluded and elevation total fasting bile acids ( $>6 \mu \mathrm{mol} /$ $L$ ) and aminotransferases (alanine and aspartate aminotransferase, ALT, AST) ( > $45 \mathrm{IU} / \mathrm{L}$ ).

Data concerning maternal age, gravidity and parity, obstetric outcome (vaginal birth vs. C-section), and gestational age at delivery were collected.

The study was approved by the local Ethics Committee in accordance to the Helsinki Declaration, following some models verifyed in other published data [18-20]. 


\section{Results and discussions}

A total of 21 cases of ICP were diagnosed during the study period: $5(23 \%)$ in 2016, $12(54 \%)$ in 2017, and 5 (23\%) in 2018 (fig. 2).

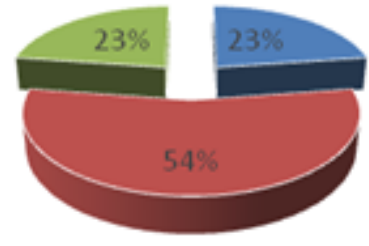

Fig 2. The ICP cases in 2016, 2017, and respectively in 2018 (in percentages)

- 2016 = $2017=2018$

Pregnant women enrolled in the study were between 21 and 46 years of age. Distribution by age groups is presented in table 1 and figure 3 .

Table 1

DISTRIBUTION BY AGE GROUPS OF THE ICP CASES

\begin{tabular}{|l|c|c|c|c|}
\hline & $\mathbf{2 0}-\mathbf{2 5}$ & $\mathbf{2 6}-\mathbf{3 0}$ & $\mathbf{3 1} \mathbf{- 3 5}$ & $\mathbf{3} 36$ \\
\hline $\mathbf{2 0 1 6}$ & 2 & 1 & 2 & - \\
\hline $\mathbf{2 0 1 7}$ & 1 & 5 & 5 & 1 \\
\hline $\mathbf{2 0 1 8}$ & - & 4 & 1 & - \\
\hline
\end{tabular}

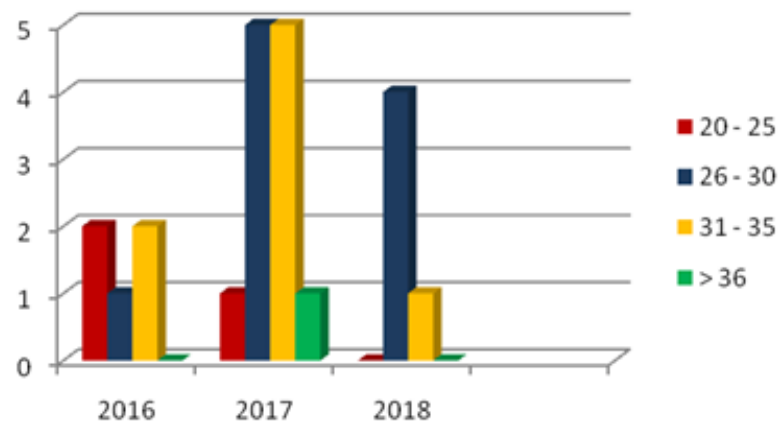

Fig 3. Graphical distribution by age groups of the ICP cases

ICP was diagnosed prior to 34 weeks of gestation in 5 cases, betw een the 34 - 37 weeks of gestation in 10 cases, and after the 37 week of gestation in 7 cases (table 2).

Most of the women with OC from our study group were primiparous (fig. 4), and delivered by C-section (fig. 5).

Table 2

THE GESTATIONAL AGE AT ICP DIAGNOSIS / BIRTH

\begin{tabular}{|c|c|c|c|}
\hline \multicolumn{2}{|c|}{$\begin{array}{c}\text { Gestational age at } \\
\text { ICP diagnosis }\end{array}$} & $\begin{array}{c}\text { Gestational age at the time } \\
\text { of birth }\end{array}$ \\
\hline$<34$ weeks & 5 & $<34$ weeks & 1 \\
\hline$<37$ weeks & 10 & $<37$ weeks & 14 \\
\hline$>37$ weeks & 7 & $>37$ weeks & 7 \\
\hline
\end{tabular}

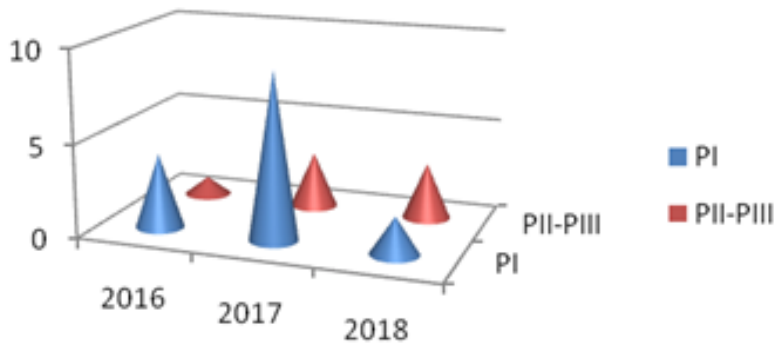

Fig. 4. Parity of ICP patients

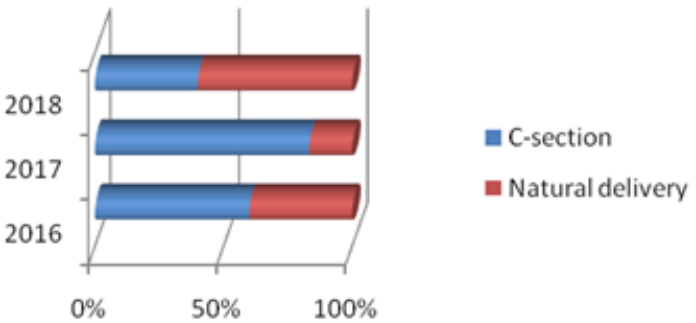

Fig 5. Percentage of Cesarean section vs. natural birth in ICP cases

\section{Pharmacologic treatment}

The primary objective of the pharmacologic treatment in ICP is to alleviate maternal symptoms and improve fetal outcome. Antihistamines, benzodiazepines, phenobarbital, opioid antagonists, dexamethasone, epomediol, Sadenosyl-L-methionine and cholestyramine have been used, but not introduced into clinical practice because of limited efficacy and/or tolerability [1-3, 21].

Currently, the hydrophilic bile acid UDCA is the most effective treatmentfor ICP. In an open, randomized, parallel group study, 84 symptomatic patients with ICP were randomized to either UDCA, 8-10 mg/kg body weight per day, or cholestyramine, $8 \mathrm{~g}$ per day, for 14 days. Relief of pruritus was significantly more pronounced in the UDCA group and serum alanine and aspartate aminotransferase (ALT, AST) activities and endogenous serum bile acid levels were more effectively lowered after UDCA therapy. In addition, delivery occurred closer to term in patients treated with UDCA [4, 22-25].

The mechanisms underlying the beneficial effects of UDCA in ICP are not entirely clear. UDCA has been shown to improve impaired hepatocellular secretion by mainly posttranscriptional stimulation of canalicular expression of key transport proteins like the apical conjugate export pump, MRP2 (ABCC2), or the bile salt export pump, BSEP (ABCB11). In particular, targeting and insertion of these transporter proteins into the canalicular membrane by UDCA conjugates has been demonstrated in experimental models of cholestasis, which led to enhanced elimination of bile acid metabolites and other organic anions as well as steroid mono- and disulfates [8, 9]. This mechanism might be crucial for the understanding of the beneficial effect of UDCA in ICP.

In addition to the effects of UDCA on the maternal liver, UDCA restores the impaired maternal-placental bile acid transport across the trophoblast. This could be mediated by enhanced expression of plasma membrane transporters involved in the excretory role of the placenta and would prevent structural alterations of the trophoblast induced by maternal cholestasis [5, 10].

Some other treatments are still under investigation. Topical emollients like baby cream, oils and aqueous cream with menthol are safe to use in pregnancy and for some patients will calm down the pruritus even just for a while. There are no trial data to prove a benefit for using this products. Many drugs have been used without clear evidence of efficacy: antihistamines, benzodiazepines, phenobarbital, dexamethasone, epomediol, S-adenosyl-Lmethionine, opioid antagonists and cholestyramine [1, 11, $12,26,27]$.

Cholestyramine binds bile salts and interrupts their enterohepatic circulation. Some studies showed that cholestyramine might improve materal morbidity but had no influence in improvement of fetal outcome $[13,14]$. Cholestyramine could contribute in malabsorption of fatsoluble vitamins, especially vitamin K. A case report of severe fetal intracranial hemorrahage during treatment with 
cholestyramine for ICP showed that severe maternal vitamin $\mathrm{K}$ deficiency might lead to fetal vitamin $\mathrm{K}$ deficiency and coagulopathy [14, 28-31].

Dexamethasone is not effective in alleviation of pruritus or ALT reduction, and was less efficientl in reducing bile acids and bilirubin levels than UDCA [3].

ICP has been associated with higher frequency of fetal distress and even intrauterine death. UDCA is the most promising treatment for ICP; it is well tolerated by mother and no adverse effects in newborns have been observed.

In our retrospective study, both total bile acide leves and concentrations of ALT decreased after starting the UDCA medication.

Preterm deliveries happened in 13 cases from our study, while C-section was performed in $68.18 \%$ of the cases.

One study reported in UK patients revealed that dexamethasone was not an universally effective treatment for $\mathrm{OC}$, but might be an effective treatment for Asian and South-American women who failed to respond to UDCA. Potential side-effects both for mothers and babies could happen, but none of them where reported, except for one case of maternal hyperglycaemia. Anyway, larger studies are needed in order to evaluate benefits and side-effects of dexamethasone in pregnancy cholestasis [15].

Insufficient data were published about the efficiency of S-adenosyl methionine in controling maternal symptoms in pregnancy cholestasis or for improving fetal outcome. It is not a recommended drug in this pathology. The few published studies demonstrated no difference in reducing pruritus and liver function tests (LFTs) levels according to NICE guide of OC.

Ribalta J. et al. perormed a double-blind retrospective study enrolling 18 women with OC treated with S-adenosyl methionine and placebo. After 20 days of treatment, no improvement was noticed; no significant differences in pruritus or in serum levels of bile salts, ALT, bilirubin and alkaline phosphatases were seen. Also no relevant sideeffects were detected [16].

A recent article revealed a new alternative treatment in pregnancy cholestasis: therapeutic plasma exchange, proved to lower bile acids serum levels and improve itch through removal of pruritogens. However, this treatment is restricted because has a limited current experience, potential complications and minimal symptomatic benefits, being used only in cases in which other treatment options have been exhausted [17].

A second double-blind, placebo-controlled trial comparing UDCA ( $1 \mathrm{~g}$ per day for three weeks) and dexamethasone ( $12 \mathrm{mg}$ per day for one week) in 130 women with ICP demonstrated a significant improvement of serum ALT and bilirubin levels irrespective of disease severity only in the UDCA group, and a significant improvement of pruritus in the UDCA subgroup with an initial bile acid level $<40 \mu \mathrm{mol} / \mathrm{L}$ (at enrollment). By contrast, dexamethasone did not alleviate pruritus, and serum bile acids and bilirubin were less effectively reduced compared to the UDCA group. However, no differences in fetal complications were detected, possibly due to the fact that fetal complications were less frequently observed in the whole study population than in previous studies [3].

In a retrospective, non-randomized analysis of a 12-year observation period, 32 patients with ICP were treated with UDCA ( $15 \mathrm{mg} / \mathrm{kg} / \mathrm{day}$ ) for three or more weeks before delivery and compared to 16 historical untreated controls with similar clinical and biochemical characteristics. UDCA treatment significantly improved pruritus intensity and some biochemical markers of ICP and resulted in a higher proportion of deliveries at term with a higher birth weight compared to historical controls $[5,6]$.

A recent randomized prospective comparative study of UDCA (750 mg per day) and S-adenosyl-L-methionine (1000 mg per day intravenously) of 78 patients with ICP suggested that both regimens improved pruritus, but the combined therapy had no additive effect on pruritus as compared to UDCA monotherapy [7].

UDCA seems to be well tolerated by pregnant women and no adverse effects in mothers or newborns have been reported $[3,4,6,7]$.

\section{Psychological counseling}

The patients enrolled in our study received counseling during 14 sessions of group therapy in order to reduce the level of anxiety and emotional distress and to prevent depression.

If needed, when prescribing medication, the pharmacological intervention should be personalized and carefully chosen in correlation with the pharmacogenetical and psychological profile of the patients, in order to prevent potential adverse events and for improved life quality [3235].

Cognitive restructuring techniques, breathing and relaxation control techniques (autogenous training Schult $\mathrm{\text { }}$ ) were applied. During therapy, the patients completed a personal diary in which they described daily personal experiences, results of exercises and themes [36-38].

\section{Conclusions}

Intrahepatic cholestasis of pregnancy is a high-risk condition which needs careful fetal assessment and appropriate medical intervention for an improvement of perinatal outcome.

Ursodeoxycholic acid proved to be safe and effective in intrahepatic cholestasis of pregnancy, to reduce maternal liver function tests, was well tolerated by pregnant women and no fetal or neonatal side effects were detected. The majority of delivery were $<37$ weeks and were performed by C-section.

Ursodeoxycholic acid is currently considered as firstline therapy for pregnancy cholestasis.

Some other drugs are still under investigation for more treatment options.

Future studies are needed for a better understanding of intrahepatic cholestasis of pregnancy pathogenesis, genetic risk profiling which may improve precocious diagnosis and identify the obstetrical management near pregnancy term.

\section{Refereances}

1.LAMMERT, F., MARSCHALLH, U., GLANTZ, A., MATERN, S.J ., Hepatol., 33, nr. 6, 2000, p. 1012.

2.PALMER, D.G, EADS, J. J., Perinat. Neonatal. Nurs., 14, nr. 1, 2000, p. 39.

3.GLANTZ, A., MARSCHALL, H.U., LAMMERT, F., MATTSSON, L.A., Hepatology, 42, nr. 6, 2005, p. 1399/

4.KONDRACKIENE, J., BEUERS, U., KUPCINSKAS, L., Gastroenterology, 129, nr. 3, 2005, p. 894.

5.POUPON R., Liver International, 25, nr. 3, 2005, p. 467.

6.ZAPATA, R., Liver Int., 25, nr. 3, 2005, p. 548.

7.BINDER, T., SALAJ, P., ZIMA, T., VITEK, L.,J. Perinat. Med., 34, nr. 5, 2006, p. 383.

8.PAUMGARTNER, G., BEUERS, U., Hepatology, 36, nr. 3, 2002, p. 525. 9.BEUERS, U., Nat. Clin. Pract. Gastroenterol. \& Amp; Hepatol., 3, 2006, p. 318.

10.SERRANO, M.A., J. Hepatol., 28, nr. 5, 1998, p. 829.

11.RIELY, C.A., BACQ, Y., Clin. Liver Dis., 8, nr. 1, 2004, p. 167/ 
12.REYES, H., J. Gastroenterol. Hepatol., 12, nr. 3, 1997, p. 211.

13.J ENKINS, J.K., BOOTHBY, L.A., Ann. Pharmacother., 36, nr. 9, 2002, p. 1462.

14.SADLER, L.C., LANE, M., NORTH, R., Br. J. Obstet. Gynaecol., 102, nr. 2, 1995, p. 169.

15.DIAC, M., J. Obstet. Gynaecol., 26, nr. 2, 2006, p. 110.

16.RIBALTA, J., Hepatology, 13, nr. 6, 1991, p. 1084.

17.0VADIA, C., J. Clin. Apher., 33, nr. 6, 2018, p. 638.

18.AGHEORGHIESEI CORODEANU, D.T., POROCH, V., 6th LUMEN International Conference on Rethinking Social Action Core Values, 16-19 April 2015, Iasi, Romania, Rethinking Social Action. Core Values, p. 33.

19.ROGOZEA, L., REPANOVICI, A., CRISTEA, L., BARITZ, M., MICLAUS, R., PASCU, A., Proceedings of the 4th WSEAS/IASME International Conference on Educational Technologies (Edute'08), Book Series: Recent Advances in Computer Engineering, Corfu, Greece, 2008, Oct. 26-28, p. 87.

20.POROCH, V., AGHEORGHIESEI, D.T., Postmodern Openings, 9, no. 2, 2018, p. 225.

21.CHIRIAC, D.V., HOGEA, L.M., BREDICEAN, A.C., REDNIC, R., NUSSBAUM, L.A., HOGEA, G.B., GRIGORAS, M.L., J. Morphol. Embryol., 58, nr. 3, 2007, p. 1023.

22.HOGEA, L.M., TUTA SAS, I., POROCH, V., NUSSBAUM, L.A., SAS, I., SERBAN, D., ERDELEAN, D., FOLESCU, R., ZAMFIR, C.L., BREDICEAN, C.A., SIMU, M.A., Rev. Chim. (Bucharest), 69, no. 4, 2018, p. 934. 23.POPA, Z., CHIRIAC, V.D., COBEC, I.M., Rev. Chim. (Bucharest), 68, no. 10, 2017, p. 2459.

24.POPOVICI, D.C., IONITA, I., IONITA, C., Rev. Chim. (Bucharest), 68, no.10, 2017, p. 2463.

25.MIOC, M., AVRAM, S., TOMESCU, A.B., Rev. Chim. (Bucharest), 68 no. 3, 2017, p. 500.

26.MRANOVICI, M.I., PUSCASIU, L., CRAINA, M., IACOB D., CHIRIAC, V.D., IONITA, I., MOLERIU, R.D., FURAU, G., SISU, A., PETRE IZ., ReV. Chim. (Bucharest), 68, no. 12, 2017, p. 2970.
27.NAVOLAN, D., BIRSASTEANU, F., CARABINEANU, A., CRETU, O., BADIU, D.L, IONESCU, C.A., MEHEDINTU, C., VLADAREANU, S., CRAINA, M., BOIA, M., CIOHAT, I., CRACIUNESCU, M., SIMU, S., NEMESCU, D., Rev. Chim. (Bucharest), 68, no. 10, 2017, p. 2234.

28.BUDA, V., ANDOR, M., CRISTESCU, C., VOICU, M., SUCIU, L., MUNTEAN, C., CRETU, O., BALBATA, D.E., GHEORGHIU, C.M., TOMESCU, M. C., Farmacia, 64, no. 3, 2016, p. 382.

29.BUDA, V., ANDOR, M., PETRESCU, L., CRISTESCU, C., BAIBATA, D.E., VOICU, M., MUNTEANU, M., CITU, I., MUNTEAN, C., CRETU, O., TOMESCU, M.C., Int. J. Mol. SCi., 18, no. 2, 2017.

30.CRETU, O.M., HUT, E.F., DAN, R.G., SIMA, L.V., BLIDIäEL, C.I.A., LIGHEZAN, D.F., MUNTEANU, M., RATIU, I.M.., Rom. J. Morphol. Embryol., 58, no. 4, 2017, p. 1295.

31.GAVRIS, C., POROCH, V., SIMION, L., BARACAN, A., TOADER, E., PASCU, A.M., Rev. Chim. (Bucharest), 68, no. 7, 2017, p. 1586.

32.ANDREESCU, N.I., NUSSBAUM, L.A., HOGEA, L.M., GRADINARU, R.C., MUNTEAN, C., STEFANESCU, R., PUIU, M., Farmacia, 64, no. 5, 2016, p. 736.

33.NUSSBAUM, L.A., ANDREESCU, N.I., HOGEA, L.M., MUNTEAN, C., STEFANESCU, R., PUIU, M., Farmacia, 64, no. 6, 2016, p. 868.

34.NUSSBAUM, L.A., HOGEA, L.M., ANDRESCU, N.I., GRADINARU, R.C., PUIU, M., TODICA, A., Rom. J. Morphol. Embryol., 57, no. 3, 2016, p. 959.

35.NUSSBAUM L.A., OGODESCU A., HOGEA L.M., NUSSBAUM L., ZETU I., Review of Research and Social Intervention, 56, 2017, p. 114. 36.HOGEA, L.M., NUSSBAUM, L.A., CHIRIAC, D.V., Rom. J. Morphol. Embryol., 58, no. 3, 2017, p. 767.

37.HOGEA, L.M., HOGEA, B.G., NUSSBAUM, L.A., CHIRIAC, V.D., GRIGORAS, M.L., ANDOR, B.C., LEVAI, C.M., BREDICEAN, A.C., Rom. J. Morphol. Embryol., 58, no. 1, 2017, p. 175.

38.NUSSBAUM, L.A., HOGEA, L.M., CHIRIAC, D.V., GRIGORAS, M.L., FOLESCU, R., BREDICEAN, A.C., ROSCA, E.C.I., MUNCAN, B., NUSSBAUM, L.M., SIMU, M.A., LEVAI, C.M., Rom. J. Morphol. Embryol., 58, no. 4, 2017, p. 1435.

$\overline{\text { Manuscript received: } 24.08 .2018}$ 